\title{
Materials Research - Ibero-american Journal of Materials \\ Judicious, fair and educative!
}

This issue of Materials Research contains 19 articles: 9 selected from regular submissions in the period 2005-2006, and 10 biomaterials related papers carefully selected from hundreds presented in the $4^{\text {th }}$ COLAOB (Latin American Congress of Artificial Organs and Biomaterials) held in Caxambú, MG, Brazil, in August 2006. The review process of all these papers was done via internet: the papers submitted in electronic format were e-mailed to two referees each, the reviews were received by e-mail, and it all worked out quite well. All the procedures necessary to assemble the present issue were carried out via e-mail. We are still testing a software interface for on-line submission, evaluation and manuscript follow-up which, hopefully, will significantly improve the interaction of authors and referees with the editors.

Seventy seven regular articles are being reviewed at present. We have also started the selection process of papers presented at the $17^{\text {th }}$ CBECIMAT (Brazilian Congress of Materials Science and Engineering) held in Foz do Iguaçu, Brazil, in November. From 110 submitted papers, 56 were pre-qualified by CBECIMAT's technical committee and are now undergoing a regular review process. Articles presented at the annual meeting of the Associação Brasileira de Metalurgia e Materiais (ABM) are also under evaluation. We should emphasize again that we do not publish conference proceedings; instead we judiciously select papers presented at different conferences, which are viewed by our team as important sources of articles for thematic issues. Materials Research pre-selected conference papers are analyzed by two referees each using the same criteria applied for the regular papers.

We gratefully thank CNPq and the organizers of the $4^{\text {th }}$ COLAOB for funding the editing and printing costs of this issue of Mat. Res. Financial support from Departamento de Engenharia de Materiais, Universidade Federal de São Carlos - DEMa/UFSCar - for mailing expenses; from Laboratório de Materiais Vítreos - LaMaV/UFSCar for fax and telephone expenses are gratefully acknowledged. Associação Brasileira de Metalurgia e Materiais - ABM - and Associação Brasileira de Polímeros - ABPol - have contributed for the editorial assistant's salary. The secretaries of Associação Brasileira de Cerâmica - ABC - ABPol and ABM have helped advertising Materials Research and with the management of its subscriptions and financial resources. 